\title{
Reason for Treatment Interruption
}

National Cancer Institute

\section{Source}

National Cancer Institute. Reason for Treatment Interruption. NCI Thesaurus. Code C102703.

The reason the drug or therapy was temporarily ceased. 